Localizador: 20006 doi: 10.35366/93972

\title{
El mundo cambió
}

\author{
The world changed
}

Omar Lupi*

$\mathrm{L}$ a pandemia de COVID-19 se ha extendido $ـ$ por todo el mundo en los últimos meses. Miles de personas están muriendo y sufriendo como no se había visto en 100 años, desde la gran pandemia de 1917/18, causada por el virus de la gripe, la más grande de toda la historia. Más de la mitad de la población mundial ahora vive en cuarentena. Estamos enfrentando un momento histórico y muy difícil.

La pandemia de coronavirus marca el final del siglo XX. Había una impresión entre los sociólogos de que faltaba un hito para recalcar el fin del siglo; una época altamente marcada por el uso de la tecnología; dicho hito es esta pandemia. Algunos historiadores creen que el siglo XIX sólo terminó después de la Primera Guerra Mundial (1914/19). Usamos el tiempo como un marcador imaginario; terminó el siglo y todo cambió. Pero las cosas no funcionan así en la vida real, la experiencia humana es la que construye el tiempo. El largo siglo XIX sólo terminó con la Primera Gran Guerra, con muertes y con la experiencia del duelo, pero también con reflexiones sobre nuestra capacidad destructiva. Creo que la pandemia de COVID-19 realmente marca el final del siglo XX y el comienzo de algo nuevo.

La medicina está siendo fuertemente influenciada por la situación actual y muchos paradigmas están siendo revisados. Es un momento de gran sufrimiento; sin embargo, también de rápido desarrollo en nuevos antivirales, métodos de diagnóstico y técnicas prometedoras en inmunización. El virus SARSCoV-2 es el enemigo a derrotar, y así será. La dermatología ha hecho su enorme contribución en este momento, con la descripción de lesiones dermatológicas involucradas en la nueva enfermedad, ayudando en el diagnóstico precoz de la enfermedad, así como en aliviar la incomodidad y el sufrimiento de millones de profesionales de la salud en todo el mundo. Las dermatitis y lesiones causadas por el uso constante de equipos de protección personal, y también por la asepsia rigurosa y repetitiva de la piel, que se ha convertido en obligatoria, son un campo que conocemos bien y en el que podemos ayudar mucho.

No obstante, hay grandes desafíos por delante. Algunos países asiáticos están logrando controlar la pandemia de COVID-19 sin cuarentenas; países populosos y de invierno frío, como Japón, tienen pocos casos de infección y baja letalidad por el nuevo coronavirus. Incluso en China, epicentro de la pandemia, el control se logró con bastante facilidad en comparación con Italia, España y los Estados Unidos. En Asia, aun en los países democráticos, algunos regímenes políticos interfieren mucho más en la vida cotidiana de las personas que en la mayoría de los países occidentales, y esto ha facilitado el control de la pandemia. En Corea del Sur los datos de ubicación de sus viajes y los locales en donde realiza sus compras son utilizados para rastrear todos sus contactos, ya que podrían ser portadores si se enferma. En China hay reconocimiento facial en todas partes, y si se acerca a cualquier lugar donde hubiera casos de COVID-19 recibirá el mensaje de una aplicación para alertarlo. Los resultados en el control de la pandemia con estas tecnologías y el acceso a los datos personales de cada ciudadano son indiscutibles. Aun así, zusted aceptaría vivir en una sociedad de ese tipo? ¿Renunciaría a su privacidad para tener mayor seguridad y ayudar a su país a controlar con más facilidad la pandemia? Estas son respuestas que ayudarán a dar forma a nuestro futuro.

El mundo está cambiando rápidamente. La era postpandemia será profundamente diferente del mundo en el que vivíamos hace pocos meses, porque mientras dormías, iel mundo cambió!

Correspondencia:

Omar Lupi

E-mail: omarlupi@globo.com 
Localizador: 20006 doi: $10.35366 / 93973$

\section{0 mundo mudou}

\author{
El mundo cambió
}

Omar Lupi*

A pandemia pelo COVID-19 se espalhou por todo o mundo nos últimos meses. Milhares de pessoas estão morrendo e sofrendo como não víamos há 100 anos, desde a grande pandemia de 1917/18 provocada pelo vírus influenza - a maior de toda a história. Mais da metade da população mundial vive hoje em quarentena. Estamos enfrentando um momento histórico e muito difícil.

A Pandemia do Coronavírus marca o fim do século 20. Havia a impressão entre os sociólogos de que faltava um símbolo para marcar o fim do século, uma época altamente marcada pelo uso da tecnologia. E esse marco é pandemia do coronavírus. Historiadores acreditam que o século 19 terminou apenas depois da Primeira Guerra Mundial (1914/19). Nós usamos o tempo como um marcador imaginário; virou o século e tudo mudou. Mas as coisas não funcionam assim na vida real, a experiência humana é que constrói o tempo. O longo século 19 terminou apenas com a Primeira Grande Guerra, com mortes e com a experiência do luto, mas também com as reflexões sobre a nossa capacidade destrutiva. Acredito que a pandemia pelo COVID-19 marca verdadeiramente o final do século 20 e o começo de algo novo.

A Medicina está sendo fortemente influenciada pela situação atual e muitos paradigmas estão sendo revistos. É uma época de grande sofrimento, contudo, também de rápido desenvolvimento de novos antivirais, métodos diagnósticos e técnicas promissoras em imunização. O vírus SARS-CoV-2 é o inimigo a ser derrotado e será. A Dermatologia tem dado sua enorme contribuição neste momento na descrição de lesões dermatológicas envolvidas na nova moléstia, auxiliando no diagnóstico precoce da doença e ajudando a aliviar o incômodo e o sofrimento de milhões de profissionais de saúde em todo o mundo. As dermatites e ferimentos causados pelo uso constante dos equipamentos de proteção individual e, também pela assepsia rigorosa e repetitiva da pele que passou a ser mandatária, são um campo que conhecemos bem e onde podemos ajudar muito.

Há, no entanto, enormes desafios surgindo. Alguns países asiáticos estão conseguindo controlar a pandemia da COVID-19 sem quarentenas; países populosos e de inverno frio como o Japão tem poucos casos de infecção e baixa letalidade pelo novo coronavírus. Mesmo na China, epicentro da pandemia, o controle foi obtido com razoável facilidade se compararmos com a Itália, Espanha e Estados Unidos. Na Ásia, mesmo nos países democráticos, alguns regimes políticos interferem bem mais no dia a dia das pessoas do que na maioria dos países ocidentais e isto tem facilitado o controle da pandemia. Na Coreia do Sul, os seus dados de viagens e locais de compras são usados para rastrear todos os seus contatos e pessoas que possam estar contaminadas se você adoecer. Na China, há reconhecimento facial em todos os lugares e, se você se aproxima de algum local com casos da COVID-19, recebe uma mensagem de um aplicativo para alerta-lo. Os resultados no controle da pandemia com estas tecnologias e o acesso aos dados pessoais de cada cidadão são indiscutíveis. Ainda assim, você aceitaria viver numa sociedade assim? Abriria mão da sua privacidade para ter mais segurança e ajudar seu país a controlar mais facilmente a pandemia? Estas são respostas que ajudarão a moldar o nosso futuro.

O mundo está se transformando rapidamente. A era pós-pandemia será profundamente diferente do mundo em que vivíamos há poucos meses, pois enquanto você dormia o mundo mudou!

Correspondência:

Omar Lupi

E-mail: omarlupi@globo.com 